\title{
Nurse's Experiences in Implementing an Islamic Care Nursing Practice in Sharia-based Hospital Yogyakarta: A Phenomenological Study
}

\author{
Shanti Wardaningsih*, Aldina Puput Junita
}

School of Nursing Program, Faculty of Medicine and Health Sciences, Universitas Muhammadiyah Yogyakarta, Yogyakarta, Indonesia

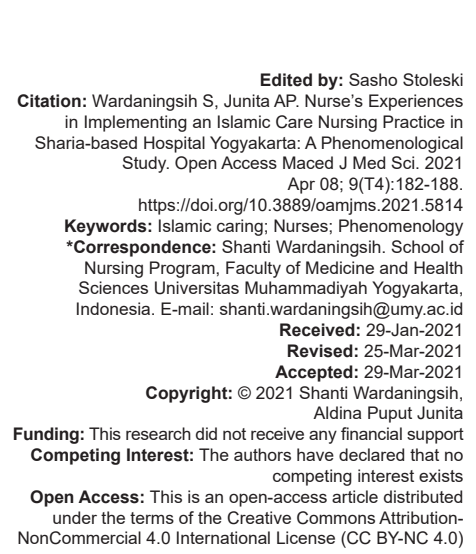

\section{Introduction}

Nurses play an important role as they are the people who provide nursing care services as the key to the patient's healing process. Nurses, as the people who are always ready for $24 \mathrm{~h}$ to provide services to the patient, have a responsibility for the patients' healing process [1]. A nurse has to serve patients with sincerity; thus, it is necessary for them to pay attention to caring practices as a depiction of compassionate nurses [2].

According to the legal constitution of the Republic of Indonesia number 38, 2014, concerning on nursing in chapter 1 article 2, it is stated that nursing practices are based on humanity, scientific value, ethics and professionalism, benefits, justice, protection, health, and patient safety. A caring practice is, therefore, very important for patient satisfaction. It can be said as a satisfying action if the implementation is in line with the patient's expectations. Darmawan's research [3] shows that there is a relationship between a caring practice and patient satisfaction. Based on his study interviews conducted, the results showed that 8 out of 10 respondents were not satisfied with nursing services.
Four of them stated that nurses were unfriendly, and the information from the nurses was unclear and slowly distributed. Meanwhile, two other respondents expressed that the nurse spoke in an inappropriate manner and impatiently dealt with the patient's complaints. Besides that, other two respondents said that in performing nursing practices, the nurses only remained silent and immediately left after the practice was completed and that the patient felt confused due to lack of information about their health. Based on the results, it can be concluded that nurse's inadequate caring practices may cause patient dissatisfaction with hospital services and affect patient's knowledge about their health.

According to the Islamic context, caring is the natural depiction of someone who loves Allah and the Prophet. Caring in Islam means being responsible, sensitive, motivated, and committed to act to achieve perfection. Islam reveals that there are three levels of caring, namely, intention, thinking, and action. Intention and thinking mean to understand what, when, and who takes care, and why. Meanwhile, action depicts how and what is the relationship between knowledge, skills, and resources embedded in the process and the result of caring [4]. 
Furthermore, nurses are considered to be a noble profession because they are the people who take care and help the patients. One of the actions is the caring practice of a nurse that can increase patient satisfaction, especially Islamic caring which includes incorporating Islamic values in the hospital regardless of the patient's status [1]. According to the research by Abdurrouf et al. [1], patient satisfaction in the Islamic surgical hospital of Sultan Agung in Semarang is influenced by Islamic caring. The Islamic caring referred to in the study consists of six aspects, namely, professionality, friendliness, trustfulness, sincerity, istiqomah, and patience. The six aspects have a big influence on the patient's comfort and satisfaction which consists of assurance, trust, responsibility, and empathy [1].

According to the preliminary study conducted on three nurses at PKU Muhammadiyah Gamping Hospital, it was found that the three nurses did not know the definition of Islamic caring. Furthermore, when they were asked about the experience of sharia practices in the hospital, they only knew that the practice includes reciting prayers when patients felt pain, and the same-gender nursing services except in a state of emergency. Therefore, it is needed to know whether nurses in Islamic hospitals understand Islamic caring and how their experiences are in carrying out Islamic caring practices in hospitals.

\section{Methods}

This research used a qualitative method with a phenomenological approach. The inclusion criteria of the participants in this study were as follows: (1) Muslim nurses, (2) nurses who work in Islamic hospital wards and have a long work experience for at least 5 years, and (3) nurses who have studied at Islamic institutions. The number of participants in this study was six nurses who worked at PKU Muhammadiyah Hospital and Nur Hidayah Hospital in Yogyakarta.

Data collection carried out in this study using in-depth interviews by researchers using a predefined interview guide. The interview stage is carried out for approximately 30-45 min in one meeting or depending on the participants' time availability. Researchers used interview guides, stationery, and voice recording devices. The interview that was conducted was to use the semi-structured interview method because in this type of method, the researcher was given the freedom to ask questions and was free to arrange the interview settings. This method uses open-ended questions, which means that the answers given by participants are not limited as long as the answers do not leave the theme and flow of the conversation [5]. Interviews were conducted directly with nurses who were willing to become research participants. Interviews were conducted once for each participant and carried out when the nurse had free time or when the nurse finished shifts. The interview was conducted in a place that had been agreed between the researcher and the participants in a conducive location. Some of the places where the interviews were conducted were in the nursing room, in front of the ward, and the hospital hall. During the interview, the researcher recorded the interview using a recorder.

The data validity of this study using triangulation techniques and member checks. This triangulation aims to check the credibility of the data. Triangulation carried out by researchers in this study was carried out using source triangulation, namely, through researchers using various data sources during the study. Sources of data come from the results of participant interviews and the document on standard operating procedures for Islamic actions by nurses. The member check in this study aims to double check whether the data obtained by the researcher from the participants are following what the participants intended. Member checks can be done by way of researchers meeting directly with participants or by communicating through communication tools or through chat.

According to Creswell, data analysis using a phenomenological approach is to use a systematic coding process. The process begins with listening to the participant's experience verbally then recording it, then continues with the verbatim transcript process, namely, typing from the recorded results during the interview [6]. Researchers analyzed specific questions then differentiated them into categories that would form a theme using open code.

This research has been approved by the Ethics committee of the Faculty of Medicine and Health Sciences, Universitas Muhammadiyah Yogyakarta (No. 556/EP-FKIK-UMY/XI/2018).

\section{Results}

There were six participants in this study; three nurses worked in PKU Muhammadiyah Hospital in Yogyakarta while the other three worked in Nur Hidayah Hospital. The characteristics of the participants are shown in Table 1.

Table 1: Characteristics of participant

\begin{tabular}{lll}
\hline Participant & Age & Length of work period \\
\hline Participant 1 & 35 years old & 9 years \\
Participant 2 & 35 years old & 12 years \\
Participant 3 & 42 years old & 20 years \\
Participant 4 & 46 years old & 23 years \\
Participant 5 & 40 years old & 5 years \\
Participant 6 & 40 years old & 15 years \\
\hline
\end{tabular}

The result of this study showed that nurse's experiences in implementing Islamic caring practice in 
Islamic hospitals consist of nurses' spiritual experiences, sharia-based services, attitudes toward Islamic caring practice, and supports and barriers in implementing Islamic caring practices. The nurse's spiritual experience includes the application of nurse's Islamic caring, the application of nurse Islamic sharia, and nurses' caring knowledge. It is in line with the participant's statement as follows: "Well, when we become a nurse, willy nilly, we have to provide caring services, especially to the patients, their families or visitors, we also have to show it..."(participant 6).

... The point is that we have to fulfill the needs of patients... such as the ADL needs, the hygiene needs, yes everything that is needed by the patient, yes, the nurses have to be caring, so we have to know how to position ourselves in front of the patient (participant 1).

The second experience of nurses in carrying out Islamic caring is sharia-based services which include how nurses communicate, how nurses help patients in religious practices, how nurses guide in the moment of sakaratul maut (dying in Islam term), and how nurses avoid ikhtilat (intermingling between men and women, in non-emergency condition), how nurses keep the patients' genitalia, how nurses provide education, how nurses fulfill the needs of patients, how nurses treat non-Muslim patients, and how nurses act collaboratively. It is revealed by the participants' statements as follows, "... or when the patients undergo sakaratul maut, we can guide them and invite the families to pray" (participant 3).

... When the prayer call comes, we remind the patients to pray... for example, if we forget to remind them to pray upon the prayer call, we can remind them when the moment we give them their daily medicine... we can ask them whether they have prayed and we can assist them. (participant 2).

... if there need actions when we have to open a patients' private organ, we have a blanket called "selimut anti malu." It is a blanket with two or three zippers so we can only open the part that we want to check (participant 1).

Furthermore, the other nurse's experience is addressing Islamic caring practices including nurses and patients' attitudes toward the implementation of Islamic caring. This is expressed by the participant's statement as follows: "Well, obviously, as a nurse we have to have a caring attitude.. do not be ignorant.. we have to be friendly with the patients" (Participant 6), "There are introvert patients as well, some do not want us to know about themselves and sometimes they give incorrect information" (participant 4).

The next experience is depicted by the supports and the obstacles in the implementation of Islamic caring including hospital policies, nurses' encouragement to practice Islamic caring, and the importance of Islamic caring. This is revealed by the participant's statement as follows:
There is a standard operational procedure made here, $h m m$... for example, when we set up a catheter, we have to teach them how to do it. The other is that when we are going to check the patient and identify what the medicine is, we have to firstly give greetings.. before they take the medicine, we encourage the patients to recite bismillah so there has already been a guideline for all nursing actions. When the action is finished, we say alhamdulillah (thank God). All of them have guidelines and it has been approved by the director (participant 2).

The obstacles in the implementation of Islamic caring include the ones coming from patients and from nurses. This is stated by the participants' statements as follows: "When there is a disaster, for example, it can affect our Islamic caring practices. It will decrease then we no longer have a will to do it as we lose our sharia foundation within ourselves" (participant 5), "Sometimes, there are patients who may deny their illness, sometimes there are those who do not want to pray even if we have told them to... and there are some who do not want to recite istigfar" (participant 2).

\section{Discussion}

\section{Nurse's spiritual experiences}

Nurses' spiritual experiences include the application of nurses' Islamic caring, the application of nurse's Islamic sharia, and nurses' caring knowledge. The nurse's performance can be seen from the process of how they practice the Islamic caring [7]. The result of this study showed that nurses have applied Islamic caring actions to patients and they stated that it is an obligation that must be done by them. In practicing Islamic caring, nurses often experience rejection from patients but they keep provide Islamic caring services. It contradicts the research conducted by Sakinah and Jannah [8] which state that the implementation of SOPs for Islamic services for nurses in Banda Aceh Hospital is less optimal due to the lack of motivation of nurses and the absence of SOP evaluations each year. Caring is one of the nursing actions. The implementation of nursing actions is based on SOPs in hospitals, including Islamic nursing practices. SOP can be considered as a good procedure if nurses carry out services based on the SOP [8].

In relation to this, the result of this research showed that the nurses as the participants in this study work in Islamic hospitals and have implemented Islamic caring based on the SOPs. Furthermore, based on the interview conducted, the nurses have the motivation that makes them work sincerely and that Islamic services provided by the nurses have been well implemented. 
Besides that, the other nurse's spiritual experience found in this study is implementing Islamic sharia such as taking care of the genitalia of the patients, taking nursing actions based on gender, and behaving kindly to the patients. An important aspect of taking care of the patients is to meet the nurse's spiritual needs by considering the spiritual needs of the patients [9]. It is in line with a literature review which states that one of the forms of Islamic caring practice is when the nurses provide services to the patients whose gender is the same as that of the nurses [4]. Moreover, this statement is in line with the standard of Indonesian Islamic Health Council, known as MUKISI, in sharia hospital $2^{\text {nd }}$ edition $1438^{\text {th }}$ version called the sharia standard of the patient's service stating that the hospital guarantees services based on gender and strives to take care of patient's genitalia. The statement indicates that the nurses have implemented Islamic caring based on sharia hospital standard.

The next nurse's spiritual experience shows that nurses understand the definition of caring as holistic care and paying attention to patient's needs. It is in line with the previous research comparing between caring concepts from an Islamic perspective and Watson and Parse's nursing theory. According to the research, caring is the basic concept of nursing as well as the latest theory developed in the field of nursing. The development of the nursing profession influences the definition of caring that differs between certain communities and cultures and also various professions and philosophies. However, the differences produce the developed and various definitions of the concept of caring itself [10].

\section{Sharia-based services}

Other than the nurse's spiritual experiences, the sharia-based service is experienced by the nurses in implementing the Islamic caring including the way nurses communicate, help patients carry out worship, guide the patient in undergoing sakaratul maut, avoid ikhtilat elements, take care of patient genitalia, provide education, fulfill patient needs, and actions for nonMuslim patients as well as collaborative actions.

The way nurses communicate indicates their caring services. In this study, the participants communicate by paying attention to eye contact, body style, intonation, and self-introduction before the action. It is in line with the research conducted by Darmawan [3] that a good communication attitude and caring practice in the provision of nursing care can strengthen a good relationship with the patients. In addition, the research conducted by Dedi and Afiyanti [11] who showed that nurses who have empathy for their patients are the indicator of caring and that they are more responsive to their patients. The ethic of a nurse in communicating based on Islamic guidance and showing empathy is one of the caring practices. In this study, the nurses have carried out Islamic communication. Thus, caring with a good communication attitude needs to be considered so that patients and nurses have a good relationship and build mutual trust.

In another line, the nursing services in helping patients worship are such as helping patients to do ablution (wudhu) and prayer and reminding them of the prayer time. This is supported by Atkinson's study showing that all of the nurses, as the participants of his study, prayed for the patients regardless of their religion and helped Muslim patients to pray. This is part of the role of Muslim nurses [10]. Furthermore, according to Robby's research, regarding patients' perceptions toward a nurse's spiritual fulfillment, it is revealed that as a Muslim, they are obliged to carry out worship such as prayer despite being sick [12].

The result of this study indicates that one of the caring services based on Islamic sharia is to guide patients who undergo sakaratul maut. Based on the hadith of Muslim history, according to Abu Sa'id and Abu Hurairah, the Prophet Muhammad SAW said, "Guide those who undergoes sakaratul maut (dying) among you by saying laa ilaha illallah."

According to Wicaksono [13], nurses have an important role to identify the feeling of patients who are dying. Nurses have a responsibility in fulfilling the needs of patients, one of which is when the patient is in the phase of sakaratul maut. Therefore, a Muslim should be able to guide by reciting prayers to the patients to alleviate their sakaratul maut [13]. Based on the result of this study, nurses have guided the patients who undergo sakaratul maut by implementing talqin mentoring to the patients. The nurses guide the patients by reciting "la ilaaha illallah" to the patient's ear or using talqin audio if there are limited health workers at the hospital. By doing so, the nurse has fulfilled the responsibility of fulfilling the needs of patients and has carried out the guidance of the Prophet Muhammad.

In another line, the result of this study also indicates that the implementation of nursing care strives to take action based on the same gender. This is in line with the study by Miklancie [14] which states that the Qur'an encourages mutual respect between men and women. Islamic culture does not allow men to touch women. However, if it is needed for clinical reasons, the patient's family members must be present to make the women feel protected. Moreover, the Qur'an also places a high value on humility by encouraging both Muslim men and women to appreciate simplicity, and some Muslim women to keep their entire bodies covered except for their faces, hands, and feet [14].

Nurses take care of the genitalia of patients by creating modifications to supporting tools and always ensure that the patient's body is well taken care. Nurses also give their greetings before they come into the patients' room. This is in line with the research [8] which revealed that nurses who take care of the patient's 
genitalia by applying hijab to patients are included in the good category $(95.8 \%)$. There is a nursing standard operating procedure regarding the modification of supporting equipment such as the use of blanket called selimut anti malu which is the blanket equipped with zippers and is opened only on the part to be examined and also the use of the patient's hijab on the surgery. It indicates that various ways can be done by nurses in taking care of the patient's genitals, and they should always ensure the patients' convenience.

Aside from that, the result of this study also shows that nurses provide education such as how to pray with catheters attached and how to do shalat jamak for patients who will undergo surgery. The nurse also educates the family about the patient's needs because the family is the closest person to the patient. According to the research by Firmansyah et al. [15], nurses caring practices can be seen from one of Watson's caring curative factors, namely, the interpersonal teaching process. It indicates that providing information or education and being responsible for patients are caring actions to improve knowledge and health of the patients [15]. It relates to this study that nurses have implemented Watson's caring practices by educating patients. By doing so, they expected that the patient's knowledge can increase.

The other result of this study also indicates that fulfilling the needs of patients done by nurses includes providing treatment, making the patient feel comfortable such as keeping patient's secrets, paying attention to patient needs, and responding to patient's complaints. It is supported by Watson's nursing theory stating that one of the curative caring factors is including fulfilling the patient's basic needs holistically that cover all aspects involving the soul and spirituality [16].

Moreover, the nurses also guarantee and ensure that the needs of patients, such as food and medicine, are halal. According to Rasool in Barolia [17], Islam strictly adheres to the concepts of "halal" and "haram" that means the foods processed and cooked under Islamic sharia. It is based on the sharia hospital standard of MUKISI (Indonesian Islamic Health Council) $2^{\text {nd }}$ edition $1438^{\text {th }}$ version in the Sharia Standards of Patient Services stating that hospitals guarantee the halal food given to patients. Besides that, it is also explained that the hospital strives to avoid illicit substances in medicines.

Nurses also pay attention to non-Muslim patients by offering clergy. This is supported by the SOP of Nur Hidayah Hospital regarding the visit of spiritual development officers to non-Muslim patients. The procedure is done by offering the patient whether they want spiritual accompaniment based on their religion. If they want to, then the spiritual officer will contact religious leaders who have cooperated with the hospital. This is also supported by the SOP of Muhammadiyah Hospital of Yogyakarta regarding spiritual guidance for non-Muslim patients stating that all patients receive spiritual guidance services based on their respective beliefs. The procedure is the nurse initially gives a form of request for spiritual guidance to patients/families. The non-Muslim clerics who have cooperated with the hospital will later provide spiritual services for non-Muslim patients.

According to the previous research conducted by Rassool [17] regarding caring from an Islamic perspective, God expects Muslims to be compassionate toward others regardless of their religion. It is fully capable of fulfilling the current needs as well as the demands of new condition without eliminating the religious practices and beliefs. Although Islam clearly opposes alcoholism, sexual promiscuity, or lifestyle issues such as homosexual practices, Islam does not prohibit Muslim nurses and other health-care professionals from taking care of Muslim and nonMuslim patients [17]. Thus, the nurses' Islamic caring practice does not discriminate the religion of the patients and treat them the same as a Muslim patient according to their needs.

On the other hand, the nurses also collaborate with the hospital spiritual officer, families, national charity institution, known as LAZISMU, medical team, as well as students. This is in line with the research conducted by Ramadhan [18] stating that when patients are ill, they are not only physically ill but also psychologically, such as suffering from stress and depression. It will get even worse if the patient has to be hospitalized that will later add to the burden of their mind. Therefore, it is needed for the family to support the healing process and provide peace in mind both physically and psychologically. In addition to support from the family, it is the spiritual guide who will provide guidance because the goal is helping patients who experience psychological, social, and religious disorders in addition to their physical illness. The role of spirituality and health should consider the ways in which spirituality is improved by and delivers a means for connecting or reconnecting toward their health condition [18]. Furthermore, based on the decision of the managing director of PKU Muhammadiyah Hospital Yogyakarta number 3970/ SK.3.2/X/2015 regarding the guidelines for spiritual services, a collaboration between nurses and spiritual officers or Holistic Health Care services aims to conduct an interview and an observation on hospitalized patients at PKU Muhammadiyah Hospital, Yogyakarta.

Furthermore, the collaboration of nurses with LAZISMU aims to help lower class patients financially. This is based on the sharia hospital standard of MUKISI (Indonesian Islamic Health Council) $2^{\text {nd }}$ edition $1438^{\text {th }}$ version in the Sharia Standards of Accounting and Financial Management (SSMAK) stating that the hospital has a financial mechanism for managing lower class patients. Based on the result of the research, the nurses have collaborated with LAZISMU which indicates that the nurses take part in helping patients who have financial difficulty. 


\section{Attitudes toward Islamic caring actions}

The nurse's next experience is addressing Islamic caring practices including nurses' and patients' attitudes in the implementation of Islamic caring. The nurses' attitude in implementing Islamic caring includes being friendly in dealing with patients, wholeheartedly caring for patients, and reducing emotions and complains. This is in line with the previous research [11] stating that nurses who are friendly to patients will strengthen the relationship between nurses and patients and that patients can express their feelings to the nurse. Therefore, friendliness can foster a relationship of mutual trust between the nurses and the patients.

In terms of the attitudes, the result of this study also shows the openness of the patients' attitudes toward the implementation of Islamic caring practice. However, some patients show introversion and do not want to be treated with Islamic caring practice. This is related to the result of the research by Ilkafah and Harniyah [19] revealing that patients' perceptions toward nurses' caring practices can be influenced by the relationship between nurses and patients and also the patient's family. Nurses who can foster a good relationship with patients and their families will obtain the trust from either the patients or the families and that the patients have a positive attitude toward the nurses. Therefore, patient attitudes can differ depending on the attitude of nurses in fostering the relationship between nurses and patients.

\section{The support and the barrier in implementing the Islamic caring practices}

In terms of the support in implementing the Islamic caring practice, the result of this study shows that the hospital policies such as hospital programs in prayer time reminder, the SOP of Islamic caring practices, and the nurse's obligation to attend weekly Islamic studies are the elements that can support the implementation. The hospital also provides talqin equipment, information on how to pray and tayamum, as well as the availability of prayer equipment. Furthermore, the hospital policy to require nurses to attend weekly Islamic studies is in line with the sharia hospital standard of MUKISI (Indonesia Islamic Health Council) $2^{\text {nd }}$ edition, $1438^{\text {th }}$ version regarding the Human Capital Management Sharia Standard (SSMMI) stating that hospitals carry out the mandatory religious training for staff. The training aims to strengthen the competence of the staff toward patients' Islamic jurisprudence. Based on Nur Hidayah Hospital's SOP, the hospital has a talqin equipment in the form of a "sakaratul kit." It is an audio file with a special format, for instance, a programmed mp3 file which contains a talqin recitation for patients who undergo sakaratul maut. Talqin audio files can be used when there are limited health workers to practice talqin to patients.
The second support is from the nurses themselves where they become the driving force for the implementation of Islamic caring practice. It includes carrying out the commands of Allah and the Prophet, intending a work as worship, and having sincere care for the patients. This is supported by the research by Barolia [20] which states that the principle of Islamic caring action is based on divine revelation and the teaching of the Prophet. Ikhlas is a sincere attitude by purifying the intention to provide health services [21]. According to the research by Atkison [22], the Islamic caring practice can be proved by the form of sincerity in fulfilling the patient's needs, expressing pleasure for being able to benefit the patients, and keeping the patient's privacy. Thus, the Islamic caring practice is done by nurses in the form of worship such as sincere caring (ikhlas) for patients as it is the command of God and the Prophet.

The third support is the importance of Islamic caring practice. The result of this study reveals that Islamic caring can provide benefits for nurses, patients, as well as hospitals. The benefits for the nurses include merit, inner satisfaction, safety, and da'wah. Furthermore, the benefits for patients include the fulfillment of the patient's needs, faster recovery, the protection of patient privacy, as well as the patient's safety. Meanwhile, the benefits for hospitals are such as hospitals receive blessings and rewards for staff and increase hospital promotion. It is in line with the previous research revealing that nurses' attitudes toward the fulfillment of the patient's needs will improve the image of hospitals and the profession of nurses [11]. Satisfaction is one's feeling of pleasure on obtaining good services beyond their expectations. Patients who are given Islamic caring practices will be satisfied because they receive a good service from nurses who are professional, friendly, trustworthy, istiqomah, patient, and sincere [1]. It indicates that the higher the nurse's Islamic caring practice, the higher the patient satisfaction will be.

Despite the benefits, there are also some barriers in the implementation of Islamic caring including the ones coming from both patients and nurses. In terms of it, the result of this study shows that the barriers can possibly come from the nurse, such as the nurse's laziness. The fact that the country is far from an Islamic element and understanding is also a barrier for nurses in carrying out Islamic caring practices. Nursing services must be improved, because Indonesia is a country where the majority of the population is Muslim. According to Alharbi et al., a compassionate Muslim nurse is an individual who gives without asking for something in return, a person who cares unconditional, and a person who pursues to complete the joy of others [23].

The next barrier to the implementation of Islamic caring action comes from the patient. The result of this study indicates that there are some issues that hinder nurses in the implementation of Islamic caring 
action such as the patient's and the family's perspective about health, patient's denial on their illnesses, patient's rejection on Islamic caring practices, patient's refusal on prayers, and patient's consideration that prayers can be left due to their illnesses. It is in line with the previous research stating that one of the difficulties of nurses is the patient's family's denial about the condition of their family member's illness [24].

\section{Conclusion}

The result of this study showed that there are four themes of nurses' experiences in implementing the Islamic caring practice in Islamic hospitals in Yogyakarta. The four themes are the nurse's spiritual experiences, sharia-based services, attitudes toward Islamic caring actions, and the support and the barrier in the implementation of Islamic caring action. If Islamic values are integrated into nursing services, it is in line with the values of caring in nursing.

The limitation of this study is that this research should have been conducted in three sharia hospitals in Yogyakarta, but due to constraints, one hospital did not yet have an MoU with the researcher, so the study was only conducted in two hospitals.

\section{References}

1. Abdurrouf M, Nursalam N, Purwaningsih. Model Caring Islami terhadap Peningkatan Kepuasan Pasien (Islamic Caring Model on Increase Patient Satisfaction). Jurnal Ners. 2013;8(1):153164. https://doi.org/10.20473/jn.v8i1.3893.

2. Nurbiyati T. Persepsi Pasien Tentang Perilaku Caring Perawat Dalam Pelayanan Keperawatan. Jawa Tengah: Prosiding Seminar Nasional and Internasional; 2013. p. 256-61.

3. Tirtoyoso T, Sari M. Nurse caring behaviors and patient satisfaction: The impact of patients experience at Bukit Kemuning inpatient public health centre. Holistik Jurnal Kesehatan, Volume 14, No.3, September 2020: 486-493. https://doi.org/10.33024/ hjk.v14i3.1706

4. Ismail S, Hatthakit $\mathrm{U}$, Chinawong T. Caring science within Islamic contexts: A literature review. Nurse Media J Nurs. 2015;5(1):3447. https://doi.org/10.14710/nmjn.v5i1.10189

5. Wahyudi W, Sutria E, Azhar MU, Syisnawati S. Factors relating to nurse's caring behavior in interna ward. J Islam Nurs. 2017;2(2):83-92. https://doi.org/10.31227/osf.io/hu3ad

6. Moleong LJ. Metodologi Penelitian Kualitatif (Edisi Revisi). Bandung: Rosda; 2017.

7. Creswell JW. Research Design Qualitative, Quantitative, and Mixed Method. Los Angeles: Sage Publisher; 2018.

8. Sakinah E, Jannah N. Islamic Nursing service in a hospital in
Banda Aceh. Jurnal IImiah Mahasiswa. 2016;1(1):1-10.

9. Samsualam S, Hidayat R, Aswan KL. The Study of Exploration of Religiosity and Implementation of Muslim Spiritual Nursing Care (AKSM) for Ners Professional Students of PSIK FKM UMI Makassar In 2018. J Kesehatan. 2018;1(4):346-35. https://doi. org/10.33368/woh.v1i4.99

10. Sadat-Hoseini AS, Khosropanah AH. Comparing the concept of caring in Islamic perspective with Watson and parse's nursing theories. Iran J Nurs Midwifery Res. 2017;22(2):83-90. https:// doi.org/10.4103/ijnmr.ijnmr_311_14

11. Dedi B, Setyowati S, Afiyanti Y. Perilaku caring perawat pelaksana di sebuah rumah sakit di Bandung: Studi grounded theory. J Keperawatan Indones. 2008;12(1):40-6. https://doi. org/10.7454/jki.v12i1.198

12. Robby A. Patient's Perception on Fulfilling Spiritual Needs by Nurses in Surgical Ward. J kesehatan Bakti Tunas Husada. 2018; 17(2): 414-40. https:doi.org/10.36465/jkbth.v17i2.268

13. Wicaksono MK. Hubungan Tingkat Pengetahuan dan Sikap Perawat Terhadap Perawatan Menjelang Ajal bagi Pasien Muslim di Rumah Sakit Umum Daerah Muntilan Kabupaten Magelang (Undergraduate Thesis). 2012. Yogyakarta, Indonesia: Aisyiyah University; 2012. https://doi.org/10.31227/osf.io/m2bx4

14. Miklancie MA, Caring for patients of diverse religious traditions: Islam, a way of life for Muslims. Home Healthc Nurse. 2007;25(6):413-7. https://doi.org/10.1097/01. nhh.0000277692.11916.f3

PMid:17556925

15. Firmansyah CS, Noprianty R, Karana I. Nurse Caring Behavior Based on Jean W atson's Theory in the Raw at Inpatient Room. J Kesehatan Vokasional. 2019;4(1):33-48. https://doi. org/10.22146/jkesvo.40957

16. Muhlisin A, Ichsan B. Application of Jean Watson Conceptual Caring Model in Nursing Care. J Berita IImu Keperawatan. 2008;1(3):147-50. https://doi.org/10.23917/bik.v1i3.3752.

17. Rassool GH. The crescent and Islam: Healing, nursing and the spiritual dimension. Some considerations towards an understanding of the Islamic perspectives on caring. J Adv Nurs. 2000;32(6):1476-84. https://doi. org/10.1046/j.1365-2648.2000.01614.x

18. Wills M. Connection, action, and hope: An invitation to reclaim the "spiritual" in health care. J Relig Health. 2007;46:423-36. https://doi.org/10.1007/s10943-006-9106-x

19. Ilkafah $A$. Nurse caring behavior with patient satisfaction in the private care center inpatient room Dr. Wahidin Sudirohusodo Makassar Hospital. J Keperawatan. 2017;8(2):138-46. https:// doi.org/10.33857/jns.v1i1.43

20. Rubina B. Caring in nursing from an Islamic perspective: A grounded theory approach. Int J Hum Caring. 2008;13(1):5563. https://doi.org/10.20467/1091-5710.12.1.55

21. Hetharia R. Kecerdasan spiritual dan caring petugas kesehatan terhadap kepatuhan pasien TB. paru dalam Pengobatan. J Health Qual. 2014;4(2):77-14.

22. Atkinson C. Islamic values and nursing practice in Kuwait. J Holist Nurs. 2015;33(3):195-204. https://doi. org/10.1177/0898010114564682 PMid:25575602

23. Alharbi J, Al Hadid L. Towards an understanding of compassion from an Islamic perspective. J Clin Nurs. 2019;28(7-8):1354-58. https://doi.org/10.1111/jocn.14725 PMid:30516863

24. Arumsari DP, Emaliyawati E, Sriati A. Barriers to effective communication between nurses and the patient's family in the perspective of the nurse. J Pendidikan Keperawatan Indonesia. 2017;2(2):104-14. https://doi.org/10.17509/jpki.v2i2.4745 